\title{
Blodfortynnende midler
}

\author{
Jeg har i 50 år ergret meg over uttrykket «blodfortynnende legemidler». Midlene fortynner jo slett ikke blodet, \\ de motvirker koagulasjonen. Uttrykk som antikoagulerende eller antikoagulatorisk burde vel ikke være for \\ vanskelige i et medisinsk tidsskrift?
}

Saken ble omtalt i Språkspalten for et par år siden (1). En innsender skrev at pasientene trodde at de hadde for tykt blod, som så ble fortynnet med medisiner. Legen forklarte da at de aldri har hatt for tykt blod, og at de på sykehuset ikke hadde fått «blodfortynnende» medisin, men en medisin som nedsatte blodets evne til å koagulere, slik at faren for danning av nye blodpropper ble redusert. Dette oppfattet pasientene umiddelbart (1).

Den problematiske ordbruken gjelder ikke bare på norsk. «Blood thinning» og «blod thinner» brukes i engelskspråklig faglitteratur - og det har vært protestert mot uttrykket der også, blant annet i BMJ i 2012 (2).

\section{Mye brukt}

Ordet «blodfortynnende» må ha sterk appell. Det er registrert hele 33 ganger i Tidsskriftets nettutgave, som omfatter årgangene fra 2000 (3). Eldste treff på «blodfortynnende» i det digitale Nasjonalbiblioteket (bokhylla.no), er i Gyldendals store konversasjonsleksikon fra 1959 (4). Det har altså vært brukt lenge på norsk, også før warfarin kom på markedet i 1962. I Retriever, en søketjeneste over norske aviser, tidsskrifter og andre medier, er det registrert brukt over 4300 ganger. Det er også anvendt av Statens legemiddelverk, til og med i en artikkeltittel (5). Som om ikke det var nok, er ordet kommet med $i$ en medisinsk ordbok - selv om man i Store medisinske leksikon påpeker at det er misvisende (6).

Konklusjonen blir vel derfor at begrepet har fått hevd i språket. Det er brukt i lang tid, også i toneangivende miljøer. Og det er trolig vanlig å mene som en kollega: «Jeg tror nok kampen stort sett er tapt, blant annet fordi «blodfortynnende» er et allment akseptert uttrykk blant folk flest. Vi må tenke på at pasientene skal forstå det vi sier. For hva skal alternativet være? Når jeg som kardiolog setter en pasient på et antikoagulerende legemiddel på grunn av atrieflimmer, er det lett å forklare ham eller henne: «Siden du har fått forkammerflimmer, har du økt risiko for å få blodpropp og hjerneslag. Derfor bør du bruke et blodfortynnende legemiddel for å forebygge hjerneslag.» Dette er enkelt å forstå. Skulle jeg sagt antikoagulerende legemiddel? Lege-

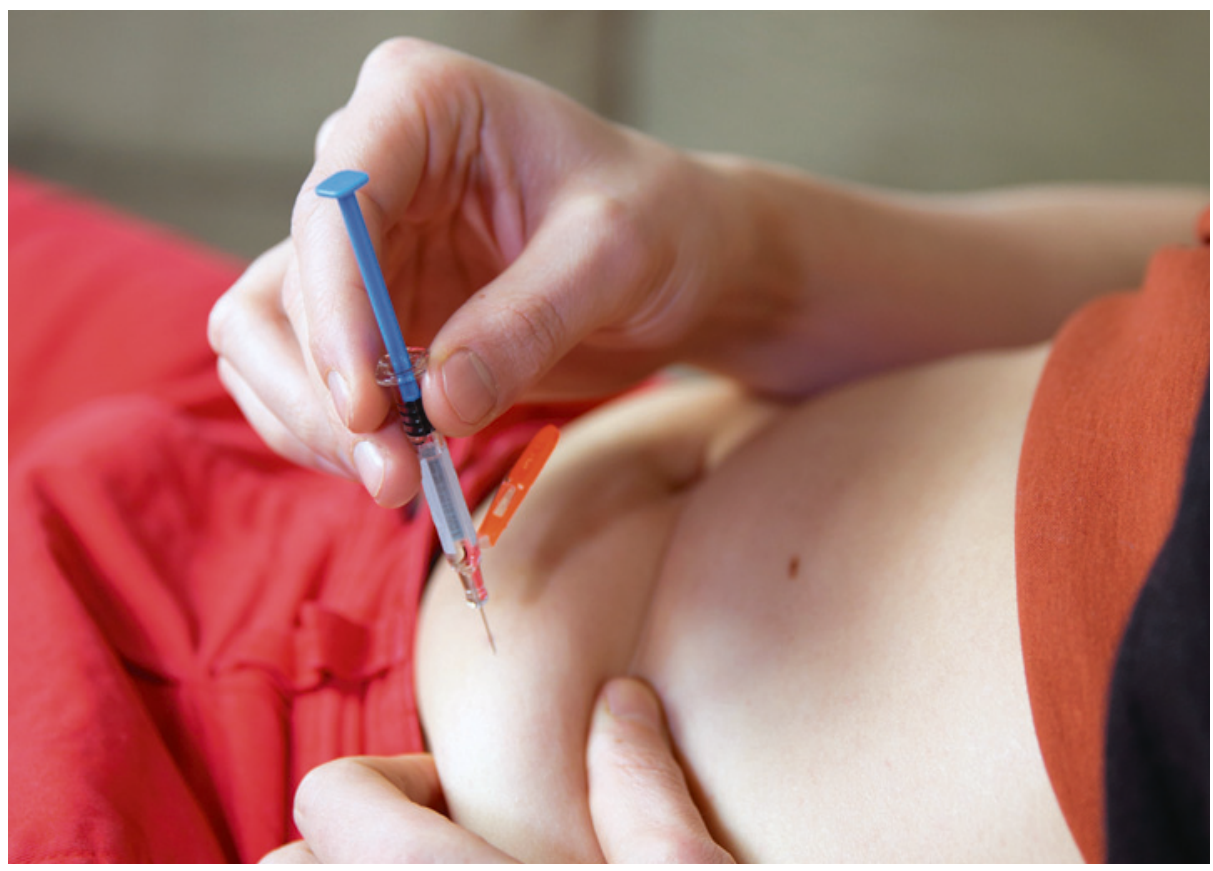

Blodfortynnende medisin kan settes med sprøyte. Illustrasjonsfoto: Thinkstock

middel som hemmer blodlevringen? Det synes jeg er dårligere alternativer.»

Kardiologen pekte imidlertid på et lite problem: «Vi bruker oftest det samme ordet om platehemmende legemidler: «Siden du har hatt et infarkt og er blitt blokket, må du bruke et blodfortynnende legemiddel resten av livet.» Det gjør det hele mindre presist, men distinksjonen er ikke så viktig for pasientene og knapt nok for leger flest. Så jeg tror vel egentlig at «blodfortynnende» er et godt ord som lett forstås. I mer formelle sammenhenger bruker jeg «blodfortynnende/blodfortynning» og «blodplatehemmer/blodplatehemming».»

\section{De tapte slag}

Jeg har selv utallige ganger forelest om blodfortynning i forbindelse med reaksjonen på blødninger, når vevsvæske fortynner blodet og blodvolumet restitueres (endret starlingbalanse).

Jeg innser at slaget er tapt, men det kan likevel ligge en tilfredsstillelse $\mathrm{i}$ å utkjempe selv tapte slag!

\section{Haakon B. Benestad}

h.b.benestad@medisin.uio.no

Haakon B. Benestad (f. 1940) er professor emeritus i fysiologi ved Universitetet i Oslo og fast medarbeider i Tidsskriftet.

\section{Litteratur}

1. Evanger N. «Blodfortynnende medisin». Tidsskr Nor Legeforen 2013; 133: 1958.

2. Woodmansey P. Let's stop «thinning the blood». BMJ 2012; 344: e4114

3. Blodfortynnende. I: Tidsskrift for Den norske legeforening. http://tidsskriftet.no/articlesearch/ $? q=$ blodfortynnende\&source $=\ll$ mosez $» \&$ order $=$ pub_date (12.2.2016).

4. Lungeemboli. I: Bull F, Eskeland A, Schieldrop EB, red. Gyldendals store konversasjonsleksikon. Bd. 3: K-P. Oslo: Gyldendal, 1959: 1747. www.nb.no/ nbsok/nb/187551f108c8012c99e894cd680800c8 ?index=2\#596 (12.2.2016)

5. Harg P, Samdal H, Simensen A et al. Kan nye blodfortynnende legemidler være mer risikable enn tidligere antatt? Tidsskr Nor Legeforen 2014; 134: 817

6. Øye I. Blodfortynnende middel. I: Store medisinske leksikon (13.2.2009). https://sml.snl.no/ blodfortynnende middel (12.2.2016). 